\title{
Between Donor Interest, Global Models and Local Conditions: Treatment and Decision-Making in the Somalia-Finland Tuberculosis Control Project, 1981-3
}

\author{
KAISA HARJU * \\ History of Sciences and Ideas, PO Box 8000, FI-90014, University of Oulu, Finland
}

\begin{abstract}
Despite numerous global health initiatives after World War II, tuberculosis still poses a major threat in sub-Saharan Africa. This article examines one attempt to tackle this problem: the Somalia-Finland Tuberculosis Control Project. Conducted in the 1980s as a bilateral development aid project between the two countries, it became the most extensive - and expensive - tuberculosis initiative in Somalia in that decade. An interesting feature of the project is that, despite a lack of previous experience in tuberculosis work in developing countries, the Finnish partner decided not to follow the WHO global guidelines designed to standardise tuberculosis activities across the developing world. Instead, Finns established their own treatment programme based on X-ray and short-course chemotherapy - otherwise rarely used in clinical practice in Africa. Through a close reading and comparison of the correspondence, project plans, memos and minutes, the article analyses the formation of this strategy. Focusing on ground-level decision-making, it argues that the decisions were based not only on a belief in the superior clinical effectiveness of these methods, but also on the fact that they better suited Finnish ambitions and project logic. Thus, the article supports the notion that donor perspectives on resources and project objectives determined what was seen as feasible treatment in a developing country. By shedding light on the debate between the supporters of short-course chemotherapy and the WHO standard treatment strategy, it also contributes to the early history of DOTS (directly observed treatment, short course).
\end{abstract}

Keywords: Tuberculosis, Finland, Somalia, WHO, Development Co-operation, Chemotherapy

* Email address for correspondence: kaisa.harju@oulu.fi

This research forms a part of my doctoral thesis project, 'Exporting Expertise: Somalia-Finland Tuberculosis Control Support and Training Project, 1980-90' and was supported by Alfred Kordelin Foundation and Oskar Öflunds Stiftelse sr. An early version of this paper was written during my research visit in the Centre for Global Health Histories, University York. I would like thank Heini Hakosalo, Seija Jalagin and Alexander Medcalf for their guidance and comments. I am also grateful to Sanjoy Bhattacharya and Arnab Chakraborty for their support and help. Finally, I would like to thank anonymous reviewers for their thoughtful and constructive feedback. 
In April and early May 1980, two Finnish tuberculosis specialists - Dr Eljas Brander and Dr Pähr-Einar Hellström - visited Somalia for two weeks as guests of the Somali Ministry of Health. As board members of the Finnish Anti-Tuberculosis Association (FATA), their mission was to collect information on the tuberculosis problem ${ }^{1}$ and investigate how FATA might support Somalia in tuberculosis control. ${ }^{2}$ The result was the founding of the Somalia-Finland Tuberculosis Control Project. ${ }^{3}$ Conducted over the decade 1980-90 as the first bilateral aid programme between the governments of the two countries, the project displayed the key characteristics of a post-war global health initiative: it was a disease-specific intervention that was carried out in Africa by agencies based in Europe, and it was built upon a general belief that the disease burden in developing countries could and should be diminished by means of know-how and material resources from the West. ${ }^{4}$ The Project received government-funding from the Finnish Department of International Development Cooperation (DIDC), and it remains one of the largest health aid initiatives that Finns have undertaken in developing countries. With a total budget of 43.5 million Euros (if converted into today's currency) and over 35000 cured patients, it was also the most extensive tuberculosis initiative in Somalia during the 1980s. ${ }^{5}$

Finland did not have a past as a colonial power, whereas other European countries did and that was what motivated them to prolong their influence in Africa - also under the aegis of development aid. ${ }^{6}$ Nonetheless, the project was still clearly tied to Finnish agendas. FATA was a major Finnish non-governmental public health organisation. It had been founded in 1907 for tuberculosis control in Finland, ${ }^{7}$ where the disease (henceforth TB) had remained a major public health issue for much longer than in the other Nordic countries. ${ }^{8}$ Once TB was no longer a threat at home, the Association turned its interests towards developing countries. Apart from the humanitarian global health

\footnotetext{
1 This article is about pulmonary tuberculosis. Caused by the airborne mycobacterium tuberculosis and spread, for example, via coughing, it can remain latent and non-infectious for years before becoming active and infectious. Active symptoms are, among others, a long-lasting cough, bloody sputum, fever, fatigue, chest pains and lack of appetite. Without chemotherapeutic intervention, developed $1950 \mathrm{~s}-70 \mathrm{~s}$, it can lead to a gradual destruction of the lungs and death or permanent disability. For a more elaborate description, see, for example, Christian McMillen, Discovering Tuberculosis: A Global History, 1900 to the Present (New Haven: Yale University Press, 2015), 8-10.

2 Archives (FA) of the Finnish Anti-Tuberculosis Association, Minutes from the FATA Board Meeting (MFB), 27 February 1980, 14/23 $\S$ and attachment.

${ }^{3}$ Hereafter referred to as the 'Project'.

4 James L.A. Webb and Tamara Giles-Vernick, 'Introduction', in Tamara Giles-Vernick and James L.A. Webb (eds), Global Health in Africa: Historical Perspectives on Disease Control (Ohio: Ohio University Press, 2013), 2-3, 11; Randall M. Packard, A History of Global Health: Interventions into the Lives of Other Peoples (Baltimore: John Hopkins University, 2016), 6-11.

${ }^{5}$ Kaisa Harju, 'Suomesta maailmalle terveyden puolesta. Somalian tuberkuloosihankkeen synty', Historiallinen aikakauskirja, 116, 1 (2018), 43-44, 52. So far, this article is the only historical study on the Somalia-Finland Tuberculosis Control Project. In general, the history of Finnish development aid is little studied. There are no publications on other Finnish medical aid projects or co-operation between Somalia and Finland prior 1990. For the number of cured patients, see Lennart Brander and Simo Grant, 'Finnish civil society organizations and the fights against Tuberculosis in Somalia', in Thomas Lothar Weiss (ed.), Migration for Development in the Horn in Africa: Health Expertise from the Somali Diaspora in Finland (Helsinki: International Organization for Migration, 2009), 164.

${ }^{6}$ Heide-Irene Schmidt and Helge Pharo, 'Introduction', Contemporary European History, 12, 4 (2003), 388, 390.

${ }^{7}$ For more on the early work of FATA, see Heini Hakosalo, 'A Twin Grip on 'The National Disease': Finnish Anti-Tuberculosis Associations and Their Contribution to Nation-Formation (1907-17)', Journal of Finnish Studies 21, 1 (2019).

${ }^{8}$ Sakari Härö, Tuberculosis in Finland: Dark Past - Promising Future (Helsinki: Finnish Lung Health Association, 1998), 10, 24-6.
} 
goals, development aid allowed FATA to continue practical anti-TB work, upon which its self-image, influential position and funding was highly dependent. ${ }^{9}$ The same move had already been seen in many other countries, for example Sweden, Norway, France and the UK. ${ }^{10}$ The Somalia Project was FATA's first development aid project. Previous contacts between Finland and Somalia had been modest and the Project began the bilateral co-operation between the two countries. ${ }^{11}$ The long-term objective was to assist the Somali National Tuberculosis Control Programme (NTCP) - under the authority of the Ministry of Health (MOH) - in its attempts to expand TB services and reduce the high prevalence of the disease in Somalia. In 1981, the immediate objective was to develop feasible case-finding and treatment measures in the Qoryoley refugee camps. ${ }^{12}$ From 1984 onwards, the Project evolved from a treatment-oriented initiative to an extensive healthcare infrastructure and education programme, operating in five of the sixteen regions of Somalia before it was suddenly terminated in 1990 with the outbreak of the Somali Civil War. ${ }^{13}$

A historically interesting feature of the Project is that, despite having no previous practical experience of TB work in developing countries, FATA decided to deviate from the twelve-month standard treatment for tuberculosis recommended by the World Health Organization (WHO) - designed to be followed throughout the developing world, and already adopted earlier by the Somali NTCP. Instead, the Finns opted for a case-finding method that relied on X-ray scanning and a drug treatment of rifampicin and varying combinations of streptomycin, isoniazid, pyrazinamide and ethambutol over a period of six months, alongside a course of chemotherapy. During the early 1990s, the six-month chemotherapy would become one of the cornerstones of the 'DOTS strategy' (directly observed treatment, short course), adopted by the WHO in 1994 to be implemented globally. The strategy is based on five elements: (i) a political commitment to tuberculosis control; (ii) the diagnosis of cases based on sputum microscopy; (iii) standard treatment with a short course of directly observed chemotherapy during at least the initial phase of treatment; (iv) a regular drug supply to ensure the uninterrupted treatment of patients; (v) monitoring programmes using a standard recording and reporting system that includes reports on treatment outcomes. ${ }^{14}$ This approach was developed by the International Union Against Tuberculosis (IUAT) during the $1980 \mathrm{~s} ;{ }^{15}$ however, as this article will demonstrate, the applicability of the short-term treatment in developing countries was still controversial in the early 1980s. The X-ray scanning was at odds with the case-finding principles of both the WHO and IUAT.

\footnotetext{
${ }^{9}$ Harju, op. cit. (note 5), 46-52.

${ }^{10}$ FA, MFB, 16 September 1968, Appendix 2a, 8-9, Appendix 2b, Table 7.

${ }^{11}$ Harju, op. cit. (note 5), 43, 52.

12 Archives of Finnish Ministry of Foreign Affairs (AMFA), 12R Suomi/Somalia: Tuberkuloosin vastustamisprojekti I (henceforth '12R SSTP I') 1980, 279; Agreement between the Government of the Republic of Finland and the Government of the Somali Democratic Republic, 29 November 1980, 2; and Appendix 1 'Plan of Operations Assistance for Tuberculosis Control Programme in Somalia', 3-5 (henceforth 'Governmental Agreement, Appendix 1').

${ }^{13}$ Harju, op. cit. (note 5), 43.

${ }^{14}$ Léopold Blanc and Mukund Uplekar, 'The present global burden of Tuberculosis', in Matthew Gandy and Alimuddin Zumla (eds), The Return of the White Plague: Global Poverty and the 'New' Tuberculosis (London and New York: Verso, 2003), 108-11.

15 Christoph Gradmann, 'Treatment on Trial: Tanzania's National Tuberculosis Program, the International Union against Tuberculosis and Lung Disease, and the Road to DOTS, 1977-91', Journal of the History of Medicine and Allied Sciences, 74, 3 (2019), 316-8.
} 
This article asks how the Finns chose and implemented this approach in Somalia in 1980-3. Explanations are sought by analysing the experiences, interests and opinions of Somali and Finnish participants; exploring the inner dynamics of the project; and looking at the international discussion concerning tuberculosis control. The article will first outline the context by mapping the background of Somalia's NTCP, the tuberculosis situation there and how global tuberculosis plans impacted on Somalia in the early 1980s. Then it will examine the reasons why the Finns initially diverged from the standard WHO approach. Lastly, the article will show how short-term treatments were implemented in practice in Qoryoley, and how these experiences influenced treatment strategy in 1982-3.

The sources include both semi-official correspondence between the key Finnish actors and official documents such as plans, reports and meeting minutes from the private archive of Finland's Lung Health Association, and governmental archives of the Finnish Ministry for Foreign Affairs. ${ }^{16}$ The global tuberculosis guidelines are drawn from previous historical research and WHO documents available in the WHO IRIS database. ${ }^{17}$ I will also refer to the interviews of five Project members, who worked in the field or in the FATA office in the period 1980-3. I interviewed them during the autumn of $2017 .{ }^{18}$ My main focus, however, is on the letters written by the leading doctors in the Finnish medical team sent to Somalia, Dr Tor-Leif Sellergren (1981), Dr Eeva Rusanen (1982), Dr Liisa Parkkali (1983) and Dr Eljas Brander, the latter of whom would become the director of FATA in 1984. ${ }^{19}$ Judging by this correspondence and interviews with former Project members, he was one of the main architects of the Project and acted as mediator between the medical team and the FATA board in 1981-3. ${ }^{20}$

The letters form a rich and immediate portrayal of the daily activities, hardships and cultural encounters made in the field. Like any sources, however, they also have their shortcomings. First, not every discussion about treatment left a written trace, since aid efforts were often planned over the phone and in unofficial meetings. ${ }^{21}$ Second, the views of the Somalis are clearly underrepresented in the written sources. The historian Sanjoy Bhattacharya has pointed out that the reliance on sources produced by people in senior positions in international non-governmental organisations (NGOs) and national governments has caused medical historians to downplay the importance of local agency and ignore contradictory visions, and therefore diminish their impact on global health initiatives. ${ }^{22}$ Although the article aims to map out the diversity of opinions and actions of the Somali side, this critique can be fairly levelled at this study, too. The Finnish archives used to contain only a few documents written by the representatives of the NTCP and

\footnotetext{
${ }^{16}$ Correspondence is stored in the Helsinki archive of the Finnish Lung Health Association (successor to FATA). Official documents mainly come from the archives of the Finnish Ministry of Foreign Affairs.

17 https://apps.who.int/iris/.

18 See transcripts, with the author, of interviews with former FATA office secretary, Maija Kajava, Helsinki, 22 August 2017; team leaders Dr Liisa Parkkali and Lasse Parkkali, Helsinki, 23 August 2017; the nurse, Inari Virmakoski, Helsinki, 24 August 2017; and the laboratory technician Heli Sellergren, Helsinki, 5 September 2017.

${ }^{19}$ Sakari Härö, Vuosisata Tuberkuloosityötä Suomessa. Suomen Tuberkuloosin Vastustamisyhdistyksen Historia (Helsinki: Suomen Tuberkuloosin Vastustamisyhdistys, 1992), 216.

${ }^{20}$ See, for example, FA; Eljas Brander Archive (EBA) 1982-3; Eero Tala to Eljas Brander, 13 January 1983; Maija Kajava, op. cit. (note 18), 1-3, 9; Heli Sellergren, op. cit. (note 18), 13.

${ }^{21}$ See, for example, Liisa Parkkali, op. cit. (note 18), 26; Heli Sellergren, op. cit. (note 18), 2, 13-14.

22 Sanjoy Bhattacharya, 'Global and local histories of medicine: interpretative challenges and future possibilities', in Mark Jackson (ed.), A Global History of Medicine (Oxford: Oxford University Press, 2018), $244-5$.
} 
$\mathrm{MOH}$, and the ones I have found do not discuss treatment. In a few instances, their opinions have also been referred to in the letters of Finnish doctors. Thus, the article analyses the formation of the treatment strategy mainly from the donor's perspective, moving between the field (in Somalia) and the central administration (in Finland).

The article makes two main contributions to the historiography of tuberculosis and global health interventions. First, by offering a detailed description on how short-term treatment was chosen, discussed and implemented at the ground level, it sheds light on the early introduction of short-course chemotherapies in Africa, which have been called 'the last major breakthrough in TB control'. ${ }^{23}$ A recent historical interest in global, post-war tuberculosis interventions has focused on important developments in South Asia, mainly prior to the 1980 s. $^{24}$ Christoph Gradmann has analysed the IUAT-supported Tanzanian National Tuberculosis and Leprosy Programme, which served as the main inspiration for the DOTS that continues to be the cornerstone of global tuberculosis-control efforts. ${ }^{25}$ Otherwise, little is known about early programmes using short-course regimens in the African context. ${ }^{26}$ By offering a parallel model for short-course chemotherapy, the article also adds to the development of DOTS, which - despite good cure rates - has also been accused of being too top-down oriented and over-simplified for various conditions in the developing world. ${ }^{27}$

Second, this article adds to the historiography of post-war global health interventions by investigating disease control in bilateral development aid settings. As Bhattacharya has pointed out, WHO officials could not directly instruct donors and national authorities in how to implement bilateral health projects. ${ }^{28}$ Packard has noted that donors bypassed the WHO policies if they were not suitable for their own agendas. ${ }^{29}$ Donor-based planning and lack of co-ordination between different aid efforts have contributed to the fact that health care interventions have often remained vertical and treatment-oriented despite the attempts of the WHO to create more holistic, basic health care centred approaches to health. ${ }^{30}$ By examining how the 'Finnish model' of TB control was imported, how it intersected with

${ }^{23}$ McMillen, op. cit. (note 1), 165.

24 ; Sunil Amrith, 'In Search of a "Magic Bullet" for Tuberculosis: South India and Beyond, 1955-65', Medical History, 17, 1 (2004), 113-30 Helen Valier, 'At home in the colonies: the WHO-MRC Trials at the Madras Chemotherapy Centre in the 1950s and 1960s', in Michael Worboys and Flurin Condrau (eds), Tuberculosis Then and Now: Perspectives on the History of an Infectious Disease (Montreal, Quebec: McGill-Queen's University Press, 2010), 213-34. Niels Brimnes, Languished Hopes: Tuberculosis, the State and International Assistance in Twentieth-Century India (New Delhi: Orient Blackswan, 2016); Margaret Jones, 'Policy Innovation and Policy Pathways: Tuberculosis Control in Sri Lanka, 1948-90', Medical History 60, 4 (2016), 514-33.

${ }^{25}$ Gradmann op. cit. (note 15). Today, DOTS is integrated into the WHO 'End TB Strategy'. See WHO Executive Board, 134th session, 'Global Strategy and Targets for Tuberculosis Prevention Care and Control after 2015: Report by the Secretariat', 29 November 2015, 5. Available online at http://apps.who.int/gb/ebwha/pdf_files/EB 134/B134_12-en.pdf?ua=1, last accessed 1 March 2019.

${ }^{26}$ For research on short-course chemotherapy, see Kirsten Moore-Sheeley, 'The Products of Experiment: Changing Conceptions of Difference in the History of Tuberculosis in East Africa, 1920s-70s', Social History of Medicine 31, 3 (2018), 533-54. For DOTS and short course chemotherapies, see also Jessica Ogden, Gill Walt and Louisiana Lush, "The Politics of "Branding" in Policy Transfer: The Case of DOTS for Tuberculosis Control', Social Science \& Medicine 57 (2003). Annik Rouillon 'The Mutual Assistance Programme of the IUATLD: Development, Contribution and Significance', Bulletin of the International Union Against Tuberculosis and Lung Disease, 66 (1991) 162-70; McMillen, op. cit. (note 1), 165, 186-223; M.C. Raviglione and A. Pio, 'Evolution of WHO Policies for Tuberculosis Control, 1948-2001', The Lancet, 359, 9308, (2002), 777-8; Helen Bynum, Spitting Blood: The History of Tuberculosis (Oxford: Oxford University Press, 2012), 256-7.

27 Ogden et al., op. cit. (note 26), 184-5.

${ }^{28}$ Bhattacharya, op. cit. (note 22), 252.

${ }^{29}$ Packard, op. cit. (note 4), 232-3, 245.

${ }^{30}$ Ibid., 7-8, 330-1. 
the WHO policies and contemporary trends of TB control, and how the clinical work balanced between the high medical standards and realities of the local conditions, the article sheds more light on the logic of bilateral health care projects and their relations to the global guidelines.

\section{Tuberculosis in Somalia}

Although the project was initiated by FATA, the Somalis also had an obvious interest in collaborating. According to an estimate, one per cent of the general population and ten per cent of the refugees in Somalia were bacteriologically positive and thus infectious. Addressing TB was one of the main targets of the MOH's five-year healthcare plan for the years $1981-5 .{ }^{31}$ It coincided with the waning of international interest in antiTB work, ${ }^{32}$ having once been one of the main targets of the WHO and the United Nations International Children's Emergency Fund (UNICEF) in the 1950s and 1960s. ${ }^{33}$ The first vertical anti-TB campaign had been implemented in Somalia in 1953 by the Italian administration of the UN trust territory of Somaliland. ${ }^{34}$ The WHO and UNICEF supported the establishment of treatment centres for TB in Hargeisa in the late 1950s, and in Mogadishu just after independence in the early 1960s. They also funded the establishment of the Somali NTCP in 1971 and its implementation in the years following. ${ }^{35}$ Such national programmes had become the WHO flagships for TB control in Africa. ${ }^{36}$ In Somalia, the aim was to expand $\mathrm{TB}$ services nationwide by establishing national tuberculosis centres and walk-in or 'ambulatory' treatment centres in each district. ${ }^{37}$ By 1980, however, TB had become a neglected disease due to the WHO running into financial difficulties, the disappearance of TB from developed countries, which decreased the general interest in the disease, disappointment with the results of TB control efforts and the Alma-Ata Declaration in 1978, which prioritised the development of primary healthcare (PHC) over specialised vertical programmes concentrating on one disease. ${ }^{38}$ The governmental agreement between Finland and Somalia notes that although there were many donors for public healthcare, there were none for tuberculosis services. The WHO and UNICEF were planning to discontinue their aid to the NTCP after 1980/1. ${ }^{39}$ Thus, a new donor was needed.

As a bilateral aid initiative, the Project was officially based on mutual negotiations between Finnish and Somali parties. ${ }^{40}$ The key Somali experts were the director general of $\mathrm{MOH}$, Dr Mohammed Muse Gure, and the director of the NTCP, Professor Yusuf Hersi.

${ }^{31}$ Governmental Agreement, Appendix 1, op. cit. (note 12), 2-3. The WHO had studied tuberculosis prevalence in Somalia in 1955-65. However, in addition to being outdated, these surveys were seen as non-representative as they did not include all population groups (e.g. nomads). Ahmed Y. Guled, Review of the Accomplishments of the NTCP 1981-90 (Helsinki: NTCP, 1992, 1-2).

32 McMillen, op. cit. (note 1), 181, 189-91.

33 Ibid., 59-62.

${ }^{34}$ Ari Serkkola, A Sick Man is Advised by a Hundred: Pluralistic Control of Tuberculosis in Southern Somalia, Kuopion yliopiston julkaisuja (Kuopio: University of Kuopio, 1994), 30.

35 Guled, op. cit. (note 31), 1-2.

${ }^{36}$ McMillen, op. cit. (note 1), 182. See also M.C. Raviglione and A. Pio, op. cit. (note 26), 776.

${ }^{37}$ Governmental Agreement, op. cit. (note 12), Appendix II: Programme for Tuberculosis Control, 2. For more on the NTCP in India, see Brimnes, op. cit. (note 24), 217, 220-1.

38 Raviglione and Pio, op. cit. (note 26), 776-7; McMillen, op. cit. (note 1), 181-4, 189-90; Ogden et al., op. cit. (note 26), 180, 182. See also Bynum, op. cit. (note 26), 229.

${ }^{39}$ Governmental Agreement, op. cit. (note 12), 1, 3 .

${ }^{40}$ Ibid. 
They made it clear that Somalia wanted assistance with expanding NTCP among the Somali population. They requested the construction and renovation of TB centres (one in every region), training for anti-TB medical teams and material support in terms of medicine, equipment and transportation. ${ }^{41}$ FATA, however, had planned to start the Project in the Qoryoley refugee camps. The camps had been established after the Ogaden War between Somalia and Ethiopia in 1978-9. The refugee situation had already received a lot of international attention, as the Somali government had recently requested international emergency aid for the camps. ${ }^{42}$ There were officially 70000 refugees in Qoryoley, ${ }^{43}$ but in 1981 Sellergren estimated the number to be only around $4500 .{ }^{44}$ Hellström and Brander drafted the first Project plan for refugee aid immediately after their visit and handed it to the Finnish Ministry of Foreign Affairs on 11 June $1980 .{ }^{45}$ This was revised by FATA in July. ${ }^{46}$ The governmental agreement between the Finns, Hersi and Muse Gure, plus the plan of operation, were drafted in August $1980 .{ }^{47}$ The long-term objective was to support the NTCP - demonstrating that both the Finns and the Somalis wanted to continue aid after $1981^{48}$ - but in practice, FATA's earlier plans from June and July were carried out. This prioritised the detection and treatment of tuberculosis in the Qoryoley refugee camps by the Finnish team (nurse, laboratory technician and X-ray technician led by a doctor), and to give practical training to their Somali counterparts. ${ }^{49}$

In the 1980s, the two most influential players in global TB policy were the WHO and the IUAT. The WHO Expert Committee's periodic reports were seen as 'guides to the global TB problem'. ${ }^{50}$ IUAT, an international NGO for tuberculosis control and umbrella organisation for national tuberculosis associations around the world, was one of the few organisations that still focused on TB in the 1980s, when most donors had lost interest in the disease. ${ }^{51}$ Like the majority of African countries,${ }^{52}$ the national tuberculosis programme in Somalia followed the WHO standard treatment: patients were diagnosed using sputum microscopy and given a long-term combination course treatment of inexpensive drugs such as streptomycin, isoniazid and thioacetazone

\footnotetext{
${ }^{41}$ See, for example, FA, EBA 1980, Yusuf Hersi and Muse Gure Muhammed, 'Unnamed Tuberculosis Control Programme for Somalia', 26 August 1980, 2-6.

${ }^{42}$ For the refugee sitiation in Somalia, see Assefaw Bariagaber, Conflict and the Refugee Experience: Flight, Exile, and Repatriation in the Horn of Africa (London and New York: Routledge, 2006), 108-11.

${ }^{43}$ FA. Sellergren to FATA, 17 January 1981.

${ }^{44}$ FA. Sellergren to FATA, 23 March 1981. The number of refugees was hotly contested. The Somali government claimed there were 500000 in 1979-81, whereas the UN High Commissioner for Refugees (UNHCR) put the number at 80000 . According to the UNHCR, the Somali government was claiming a higher number of refugees to secure more foreign aid; while the Somalis defended their position by stating that the UNHCR figures did not take into account the refugees living outside camps. See UNHCR (2000) The State of the World's Refugees 2000: Fifty Years of Humanitarian Actions (Oxford: Oxford University Press, 2000), 110; Bariagaber, op. cit. (note 42), $107-10$.

45 AMFA. 12R SSTP I 1980. STVY:n Projektihakemus [Project Application], Helsinki, 30 May 1980.

46 AMFA. 12R SSTP I 1980. STVY:n Avustusohjelma [Plan of Operation], Helsinki, 2 July 1980.

47 AMFA, 12R SSTP I 1980, David Johansson's memo in 'Somalian pakolaisleirien tuberkuloosinvastustamishanke; hallitusten välisen sopimuksen allekirjoittaminen' ['Project to Combat TB in Somalian Refugee Camps: Signing of Bilateral Governmental Agreement'], 17 November 1980.

${ }^{48}$ For more on this joint interest, see for example AMFA, 12R SSTP I 1980, Development Cooperation Secretary Taina Teräväinen to Johansson and Honkanen, 21 July 1980.

49 Governmental Agreement, Appendix 1, op. cit. (note 12), 4-5.

${ }^{50}$ McMillen, op. cit. (note 1), 146; Brimnes, op. cit. (note 24), 241.

${ }^{51}$ Bynum, op. cit. (note 26), 229.

52 WHO (1982), Tuberculosis Control (part 2), African region, 19. Journal articles. Available online at http://www.who.int/iris/handle/10665/223820, accessed 9 October 2018
} 
for twelve months. ${ }^{53}$ IUAT's Tanzania programme also followed these principles in 1977-81. ${ }^{54}$ Based on the studies undertaken in Madras (1956-9) and Bangalore, India, the WHO standard treatment was intended as a cost-effective means for combating TB. ${ }^{55}$ The challenge with TB is that it is a disease closely tied to social and environmental conditions. Inadequate living and working conditions, overcrowding, malnutrition and poverty - typically related to developing countries - all increase the risk of infection and the chances of a latent disease becoming active. Matters are often made worse by the lack of healthcare infrastructure and material resources to treat the large number of patients falling ill under such conditions. ${ }^{56}$ The WHO TB control policy had prioritised the Bacille Calmette-Guérin (BCG) vaccination campaigns rather than treatment. ${ }^{57}$ Still, the results of the Madras study especially were regarded as ground-breaking because they indicated that patients living in poor socioeconomic conditions could be cured with cheaper ambulatory treatment and multi-drug chemotherapy instead of expensive hospitalisation, which was the norm in the West. ${ }^{58}$

However, it was not possible to reproduce the encouraging results of the closely supervised Madras trials in various real-life conditions elsewhere in the developing world.$^{59}$ According to Sunil Amrith, the studies conducted in Bangalore already suggested that, although poor socioeconomic conditions did not affect clinical effectiveness per se, they did have a significant impact on the patients' chances of completing their treatment. ${ }^{60}$ Brander's travel report demonstrates that both Somali and Finnish tuberculosis specialists were aware that Somalia was a prime example of the typical problems that could befall WHO ambulatory treatment. It was demanding for both the patient and the provider, since it required regular visits to a clinic for twelve months. Patients often 'defaulted'; in other words, they stopped the treatment too soon. The prevalence of nomadic culture in Somalia also made the treatment difficult to follow through, as did the lack of ambulatory treatment centres, drugs, transportation and staff. ${ }^{61}$ Defaulting was a problem for two reasons: first, patients stayed infected and infectious; and, second, it encouraged drug-resistant strains of tuberculosis, thus rendering the standard drug regimen ineffective. ${ }^{62}$ The fact that these TB drugs were also freely sold in pharmacies only exacerbated the problem further. ${ }^{63}$

Clinically-oriented TB specialists were already concerned about this in the early 1960s. ${ }^{64}$ The long duration of the treatment was seen as one of the main obstacles, and so the British Medical Research Council (MRC) carried out trials for short-course therapies in East Africa (Studies X and R), Singapore and Hong Kong during the

\footnotetext{
53 Governmental Agreement, Appendix 2, op. cit. (note 37), 4; Guled, op. cit. (note 31), 2.

54 Gradmann, op. cit. (note 15), 325-6.

55 Amrith, op. cit. (note 24), 128.

${ }^{56}$ For a more elaborate description, see McMillen, op. cit. (note 1), 8-12.

${ }^{57}$ Niels Brimnes, 'BCG Vaccination and WHO's Global Strategy for Tuberculosis Control 1948-83', Social Science \& Medicine, 67 (2008), 863-73.

58 Amrith, op. cit. (note 24), 116-8; Valier, op. cit. (note 24), 218-9.

${ }^{59}$ McMillen, op. cit. (note 1), 138-44; Moore-Sheeley, op. cit. (note 26), 550-1.

60 Amrith, op. cit. (note 24), 119-22, 125.

${ }^{61}$ FA, EBA 1980, Eljas Brander, 'Matkakertomus Somaliaan tehdystä matkasta [Travelogue from Somalia] 19.4-5.5.80', 2-7.

${ }^{62}$ For more on defaulting and drug resistance in Africa, see McMillen, op. cit. (note 1), 140-1, 148-51, 154-5, $160-3$.

63 Serkkola 1994, op. cit. (note 34), 97, 122.

64 Brimnes, op. cit. (note 24), 189, 257-8; McMillen, op. cit. (note 1), 122-7, 144-8.
} 
1970s. ${ }^{65}$ By the 1980s, nobody doubted that they were clinically more effective. In 1982, the report of a study group of the WHO and IUAT (1981) declared that all countries should have access to short-course therapies. Six- to nine-month regimens of rifampicin made patients non-infectious within three months, and this cut down the chain of infection quickly, and also proved effective against TB strains previously resistant to the twelve-month treatment. However, the organisations also stated that the WHO standard treatment should remain a basic regimen in many developing countries. ${ }^{66}$ One reason for this was the cost. The short-course regimens violated the PHC policy of the WHO for being too expensive for developing countries to be carried out independently. ${ }^{67}$ This was also the case in Somalia, as Hersi had pointed out to Brander and Hellström that the NTCP could not afford rifampicin. It was therefore prescribed only to those patients who could pay for it themselves. ${ }^{68}$ The WHO stipulated that the price of the regimens should come down significantly before they could be used. ${ }^{69}$ Another serious concern was that difficult clinical conditions might also lead to a rise in rifampicin-resistant strains, as new regimens had not yet been clinically tested in African countries. ${ }^{70}$ Both the WHO and IUAT also rejected using mass X-ray scanning for active case-finding as it was regarded too expensive, complicated and imprecise compared to sputum microscopy, thus leading to wrong diagnoses and significant over-reporting of the cases. ${ }^{71}$ Instead, they recommended examining the sputum of symptomatic patients that independently came to the TB centres; and only bacteriologically positive infectious patients would then be treated. ${ }^{72}$

Despite the above, the WHO and IUAT clearly had different views on testing shortcourse chemotherapy in clinical practice. Due to the poor treatment results with the WHO standard treatment, IUAT started to use the eight-month regimen in clinical practice in Tanzania in 1982. The regimen was based on the research of the MRC from the 1970s. As Gradmann has pointed out, IUAT's decision ran counter to the WHO recommendations caused a serious stir between the two organisations. ${ }^{73}$

\section{Exporting the 'Finnish model'}

Whereas IUAT's Tanzania programme was first based on the WHO standard treatment, Finns ignored the global strategy right from the beginning. According to Brander, there were two reasons for this: direct funding from the Finnish government, and the resistance situation. ${ }^{74}$ Brander and Hellström had initially planned to rely on the WHO

\footnotetext{
65 Moore-Sheeley, op. cit. (note 26), 549-53; McMillen, op. cit. (note 1), 128-9, 165.

${ }^{66}$ Report of a Joint IUAT/WHO Study group, WHO Technical Report Series, No. 671, 1982, 17-18. Available online at https://apps.who.int/iris/handle/10665/41530, accessed 21 February 2019.

${ }^{67}$ Gradmann 2019, op. cit. (note 15), 331-2.

68 Travelogue from Somalia, op. cit. (note 61), 6-7.

${ }^{69}$ Executive Board, 71 (1982), Programme Committee of the Executive Board: Tuberculosis Control in the World - Situation Analysis, Progress Report by the Director-General, 5, para. 20. Available online at http://www.who.int/iris/handle/10665/160288, accessed 7 October 2018.

70 Annik Rouillon was involved in developing short course chemotherapy programmes as executive director of IUAT: Rouillon, op. cit. (note 26), 164. See also Ogden et al., op. cit. (note 26), 182.

${ }^{71}$ Brimnes, op. cit. (note 24), 225, 265.

72 WHO Expert Committee on Tuberculosis, Ninth Report, WHO Technical Report Series, No. 552, 1973, 14-16. Available online at http://www.who.int/iris/handle/10665/41095, accessed 7 October 2018; Report of a Joint IUAT/WHO Study Group, op. cit. (note 66), 14.

73 Gradmann, op. cit. (note 15), 329-32.

${ }^{74}$ FA, EBA 1981, Brander to Tor-Leif Sellergren, 15 February 1981.
} 
recommendations,${ }^{75}$ but during their visit they collected thirty-six sputum samples for sensitivity tests back in Finland. These took place in June 1980 and results indicated a high level of primary resistance to streptomycin and isoniazid. ${ }^{76}$ These were the primary drugs used in the WHO standard regimen, suggesting that, even if patients stayed in treatment for the full twelve months, many would not be cured. The duration of the treatment was also considered too long; and the second plan (made in July) noted that treatment could be reduced to eight or nine months and use more effective and expensive drugs. ${ }^{77}$ To avoid resistance, the drug combination had to include at least two drugs to which patients were found to be susceptible. By the autumn, FATA had decided to use a nine-month regimen starting with four drugs taken daily (rifampicin, streptomycin, isoniazid, pyrazinamide) ${ }^{78}$ with a follow-up phase where the drugs were taken only three times a week. ${ }^{79}$

The second plan was to base case-finding on mass screening with a-miniature $\mathrm{X}$-ray rather than just sputum samples: only those cases revealing pulmonary shadows in their X-rays would then be verified bacteriologically by sputum microscopy. Both bacteriologically negative and positive cases would be treated. The plan was to keep tabs on the resistance situation by sending sputum samples to the Public Health Laboratory in Helsinki for sensitivity tests. ${ }^{80}$ Jones connects similar mass-screening preferences in Sri Lanka to a clinical approach where physicians were committed to detect and cure all TB cases. ${ }^{81}$ Similarly, FATA stated that, instead of "constructing extensive systems, where gaining success takes time and is uncertain', ${ }^{82}$ it was aiming for fast and visible results by using methods that were the quickest and the most effective way to tackle TB. ${ }^{83}$ The above stance on 'extensive systems' can also be read as an opposition to the PHC policy of the WHO that prioritised the integration of TB programmes to the public health care services. Like IUAT's Tanzania programme, the Project paid some lip service to the PHC ${ }^{84}$ In practice, both were carried out as vertical, specialised projects. ${ }^{85}$ As a bilateral aid, the Project was not obligated to follow any international guidelines. Finns clearly had little trust in the capability of PHC in its 'mostly non-existent' state in Somalia. ${ }^{86}$ Thus, vertical TB work was seen as a better guarantee for good cure rates than PHC integration.

It is important to notice that the short-term treatment became possible only thanks to the DIDC's financial support. Brander stated that the second reason for FATA to use rifampicin-based regimens was that the DIDC had turned out to be more generous with government funding than they had first expected. ${ }^{87}$ FATA could afford to put medical effectiveness above cost considerations. As Sellergren put it in January 1981:

75 FA, MFB 28 May 1980 3/50 §; Appendix 3 'TBC-Program for the Refugee Camps', 2-4.

${ }^{76}$ FA, EBA 1980, Brander's memo 'STVY:n Somaliaprojektin nykyvaihe' ['Current State of the Somalia Project'], 28 July 1980.

77 Plan of Operation, op. cit. (note 46), Appendix 2. 'Vuoden 1980 ohjelma' [Programme for 1980'], 1.

78 Compare FA, Minutes of the Working Committee (MWC), 10 September $19809 / 74 \S$ and fax from Brander and Kajava to Muse Gure, Sellergren and Oramies, 14 February 1981. See also Kajava, op. cit. (note 18), 5.

${ }^{79}$ FA, Sellergren to FATA, 23 March 1981.

${ }^{80}$ Plan of Operation, Appendix 2, op. cit. (note 77), 1.

81 Jones, op. cit. (note 24), 529-31.

82 Plan of Operation, op. cit. (note 46), Appendix 1, 2.

${ }^{83}$ Plan of Operation, Appendix 2, op. cit. (note 77), 1; FA, Sellergren to Hersi, 7 February 1981.

${ }^{84}$ Governmental Agreement, Appendix 1, op. cit. (note 12), 3.

${ }^{85}$ For IUAT Tanzania project, see Gradmann, op . cit. (note 15), 326, 330-1.

${ }^{86}$ FA, EBA 1982-3, Sellergren, 'Some Reflexions on Dr Waldman's Comments Concerning the Finnish Tuberculosis Project in Somalia'.

${ }^{87}$ FA, EBA 1981, Brander to Sellergren, 15 February 1981. 
The patients we find should receive high-quality treatment, no matter the cost. Somali staff should be fully taught how to supervise the treatment. After we terminate the project, the Somalis can then decide if they can afford to continue this. At least they have learned the right way. ${ }^{88}$

Defining this 'right way' was based on prevalent development ideology that presupposed that donor countries such as Finland had superior knowledge and technology that could be transferred to low-income countries such as Somalia, which would in turn trigger development. ${ }^{89}$ FATA's leading role in the strategy formation was strengthened by the fact that the DIDC did not take an active role in the Project prior 1984. FATA members and DIDC officials justified the Project with the conviction that Finnish medical experts were well-equipped and better trained to tackle the problem in a developing country, especially with their recent experience of successful TB control in Finland. ${ }^{90}$ During the most active stage of the Finnish anti-tuberculosis campaign, FATA had become both wealthy and influential, ${ }^{91}$ but its board members had little to no practical experience of development aid. Only Hellström had direct personal experience, working as the doctor in Tanzania in 1969-70. ${ }^{92}$ Of the other board members, the most active in the Project were Brander, the head of a department in the Public Health Laboratory in Finland; Professor Eero Tala, head of the clinic of respiratory diseases at Turku University Hospital; ${ }^{93}$ Sakari Härö, a doctor and senior civil servant at the National Board of Health $;{ }^{94}$ and Professor Jorma Pätiälä, FATA director, having recently retired as head of the clinic for respiratory diseases at Helsinki University Hospital. ${ }^{95}$

It is not surprising with these backgrounds, that X-ray scanning and the nine-month regimen were adopted, as these were based on clinical practice in Finland. FATA was clearly aware of recent international research on the shorter chemotherapy treatments and their pertinence for developing countries, ${ }^{96}$ and this further encouraged the Finns to rely on shorter regimens. But although the four-drug combination and intermittence tallied with international research, ${ }^{97}$ the duration of the treatment tallied more with Finnish tuberculosis work, where the nine-month regimen had been tested and used since the 1970s. ${ }^{98}$ And using X-ray scanning in TB control was not altogether unheard of in Africa;

\footnotetext{
${ }^{88}$ FA, Sellergren to FATA, 14 January 1981.

89 Jan Cherlet, 'Epistemic and Technological Determinism in Development Aid', Science, Technology \& Human Values, 39, 6 (2014), 773-94, Emma Crewe and Elizabeth Harrison, Whose Development? An Ethnography of Aid (London and New York: Zed Books, 1998), 25-36.

${ }^{90}$ See Project Application, op. cit. (note 45), Appendix 3 'Miten STVY voisi auttaa Somaliaa?' ['How can FATA help Somalia?'], 1; Selma Honkanen's memo in 'Project to Combat TB', 18 July 1980; FA. EBA 1981. Tor-Leif Sellergren: 'Tuberkuloosi terveyden uhkana' ['TB as a Health Threat'].

${ }^{91}$ Heini Hakosalo, “'Tehokkainta lastensuojelu- ja tuberkuloosityötä, mitä yleensä ajatella saattaa”. Joulumerkkikodit osana tuberkuloosin vastaista kampanjaa Suomessa (1936-73)', Historiallinen aikakauskirja 113, 4 (2015), 393-4; Minna Harjula, Hoitoonpääsyn hierarkiat: Terveyskansalaisuus ja terveyspalvelut Suomessa 1900-luvulla (Tampere: Tampere University Press, 2015), 132.

92 Kyllikki Kauttu (ed.), Suomen Lääkärit 1987 (Helsinki: The Finnish Medical Association, 1988), 161.

93 Ibid., 891.

94 Ibid., 216.

95 Eero Tala, 'Jorma Pätiälä in memoriam', Duodecim, 99, 16 (1983), 1070-1.

96 Eero Tala, 'Tuberkuloosin lääkehoidon nykyvaihe', Duodecim, 92, 10 (1976), 505-513, 507, Kajava, op. cit. (note 18), 4-5.

${ }^{97}$ Intermittent regimens had been recommended in the Madras studies. Valier, op. cit. (note 24), 225. The fourdrug combination is also mentioned in a joint IUAT/WHO report, op. cit. (note 66), 17-18.

${ }^{98}$ For more on regimens used in Finland, see Tala, op. cit. (note 96), 505-7, 512; Eero Tala, 'Short-Course Chemotherapy in Clinical Practice', Scandinavian Journal of Respiratory Diseases Supplement 102 (1978), 43-7.
} 
according to the WHO, it was 'still used in some countries' there in the early 1980s. ${ }^{99}$ Brimnes and Jones note that X-ray scanning was also preferred by many local clinicians in Sri Lanka and India. ${ }^{100}$ Yet in Finland the method had a long tradition; between 1952 and 1982 all citizens over the age of fifteen were invited for a screening once every three years. ${ }^{101}$ Representatives of FATA compared Somalia's TB situation to Finland's in the 1930s, and justified the use of X-ray and directly observed treatment by referring to the recent experiences and improved TB situation in Finland. ${ }^{102}$ The fact that the mass screening was also coming to an end in Finland also probably encouraged FATA to continue the practice elsewhere. ${ }^{103}$ According to Brander, with its soon-to-be superfluous $\mathrm{X}$-ray equipment and technicians, Finland was suited to export this expertise to developing countries. ${ }^{104}$

The existence of reciprocity donor and recipient motives was not uncommon in global tuberculosis work, nor in medical development aid in general. ${ }^{105}$ Indeed, the transfer of Finnish methods is understandable also in the light of FATA's recent international reorientation. FATA had been an IUAT member since 1927 and collaborated closely with it since tuberculosis had receded in Finland. It had first participated in global tuberculosis aid by contributing funds to the IUAT Mutual Assistance Programme. ${ }^{106}$ In addition to giving fast and effective treatment to Somali patients, the methods also offered an opportunity for FATA to participate in testing and improving new treatment measures for developing countries. Soon after the work in the camps had started in 1981, Brander wrote to Sellergren that the results of X-ray scanning should be presented at an international conference to 'show how the case finding should be conducted in developing countries, for example in refugee camps' since 'the WHO experts understand nothing of it'. ${ }^{107}$ Scientific publications by the Somalia project would be scant. ${ }^{108}$ According to Maija Kajava, the former office secretary of FATA, scientific interests were not the main motive for the Project. ${ }^{109}$ Since the Project was more about practical work than scientific data collecting, its results were mostly presented in IUAT conferences and international meetings rather than more strictly scientific arenas. ${ }^{110}$

Both Hersi and the American medical experts that advised the refugee camp authority, however, were critical of FATA's plans. ${ }^{111}$ The Finnish medical team arrived in Somalia in

99 WHO (1982), Tuberculosis Control (part 2): African Region, op. cit. (note 52), 19.

100 Jones, op. cit. (note 24), 529-31; Brimnes, op. cit. (note 24), 225, 264-5.

${ }^{101}$ Härö, op. cit. (note 8) 61. Screening was obligatory, yet non-attendance was not criminalised. Approximately sixty to seventy per cent of citizens over the age of fifteen were screened.

102 FA. EBA 1981. Eero Pätiälä: unnamed memo, 20 November 1981.

103 Olavi Pukkila, 'Röntgensäteilyn käyttö tuberkuloosin vastustamisessa', Duodecim, 125, 1 (2009), 63. After 1982, screenings were targeted at specific risk groups and conducted less frequently. New legislation for infectious diseases ended mass screenings completely in 1989.

${ }^{104}$ FA, Letter from Brander to Sellergren, 15 February 1981.

105 See, for example, Valier, op. cit. (note 24), 227-8; Carola Rensch and Walter Bruchhausen, 'Medical Science Meets "Development Aid": Transfer and Adaptation of West German Microbiology to Togo, 1960-80', Medical History 61, 1 (2017), 7, 23.

106 Harju, op. cit. (note 5) 46-52.

107 FA. EBA 1981. Brander to Sellergren, 15 February 1981

108 So far, I have found only one article, see Heikki Peltola et al., 'Risk of Infection with Mycobacterium Tuberculosis Among Children and Mothers in Somalia', Clinical Infectious Diseases, 18, 1 (1994), 106-11.

109 Kajava, op. cit. (note 18), 2.

${ }^{110}$ For later participation in conferences and meetings, see the annual project reports, 1984-90, stored in FA and AMFA

111 Sellergren to Brander, 17 January 1981; Sellergren to FATA, 29 January 1981; see also Kajava, op. cit. (note 18), 6 . 
December 1980. ${ }^{112}$ On 3 February 1981, Sellergren wrote to Brander that he had been told that:

(a) X-ray machines should not be used at all in the case finding;

(b) Refugees should not be treated with anything other than WHO guideline drugs (streptomycin, isoniazid, TB1);

(c) One camp should not receive better treatment than the other camps;

(d) Refugee camps should not receive better treatment [than the rest of the Somali population]. ${ }^{113}$

Since source material on Somali motives regarding the treatment is scarce, it is difficult to say for sure, why Hersi nevertheless quickly agreed to follow FATA's methods. ${ }^{114}$ Sellergen's reasoning and promises might have had an effect. He wrote an open letter to Hersi where he justified the use of X-ray. ${ }^{115}$ As a part of the settlement, they also agreed that part of the rifampicin would be used for chronic cases in the Mogadishu TB Centre, where Hersi was stationed. ${ }^{116}$ Most importantly, however, Hersi was probably aware that the likelihood of him being able to change the Finnish methods into those recommended by the WHO were slim. Maria Eriksson Baaz and others have noted that, despite the rhetoric of partnership, the interests of the donor party often dominate in development co-operation. As a sponsor, the donor can set up 'the rules of the game'. ${ }^{117}$ In our case, this much was demonstrated already at the planning stage, since the immediate objectives followed FATA's plans. The fact that it was also a short four-month contract might have created extra pressure. ${ }^{118}$ It was evident that DIDC was interested in continuing the Project after $1981,{ }^{119}$ but since FATA had no practical experience in implementing aid and since the Project received significant funding from the Finnish government, DIDC wanted to first test the Project. ${ }^{120}$ Hersi thought that the continuation of funding would depend on the results from Qoryoley. ${ }^{121}$ As Finland was the only major donor and the continuation of aid was uncertain, it is plausible that Hersi did not want to compromise the Project by arguing too much over treatment. The refugee aid period thus functioned as a way of forging a new aid relationship that would eventually fulfil more general needs of NTCP.

\section{Towards international models}

After six weeks of preparations, negotiations and familiarisation with the local conditions in Somalia, the Finnish team and their Somali counterparts started to X-ray refugees on

\footnotetext{
112 FA. EBA. 1981. Brander: 'Selostus Suomen Tuberkuloosiprojektista Somaliassa. I kuukausi, 4.12.80-4.1.81'.

113 FA. EBA 1981. Sellergren to Brander, 3 February 1981.

114 FA. EBA 1981. Sellergren to Brander, 17 January 1981.

115 FA. Sellergren to Hersi, 7 February 1981. See also Sellergren to FATA, 18 February 1981.

116 FA. Sellergren to Brander, 17 January 1981.

117 Maria Eriksson Baaz, The Paternalism of Partnership: A Postcolonial Reading of Identity in Development Aid (London and New York: Zed Books, 2005), 73-5. For more on power relationships in global TB work, see Valier, op. cit. (note 24), 219-20.

118 FA. Sellergren to Brander, 17 January 1981.

119 Governmental Agreement, Appendix 1, op. cit. (note 12), 3.

${ }^{120}$ AMFA, 12R SSTP I 1980, Selma Honkanen to David Johansson, 30 July 1980.

${ }^{121}$ FA, EBA 1981, Hersi to Jorma Pätiälä, 12 February 1981.
} 
21 January $1981 .{ }^{122}$ The first patients were admitted for treatment on 7 February. ${ }^{123}$ The day-to-day activities in the camps were administered by Tor-Leif Sellergren, a specialist in lung diseases who, among holding other shorter medical posts, had worked since 1965 as a doctor in a TB ward in Raseborg, Finland. ${ }^{124}$ Finns and the NTCP staff did clinical work closely together. During the first months, X-ray technicians Raimo Leisilä and Mohammed Cabdi carried out X-ray scanning. Laboratory technician Aniisa Saalax prepared and examined sputum. Samples were also delivered in Mogadishu, where laboratory technician Heli Oramies examined them with the local staff. Sellergren diagnosed patients with Somali doctors Abdullah Shek Mohamed and Moxamed Giuni. Nurses Tuija-Liisa Peltola and Asha Jama Gashan administered the drug distribution. ${ }^{125}$ Finns instructed Somali counterparts in TB work, but also received valuable advice on how practical matters should be arranged in the camps. ${ }^{126}$ However, the practical decision-making on case-finding and treatment was mainly in the hands of Sellergren. Despite their early differences, he and Hersi shared a mutual respect and seem to have had a good working relationship. ${ }^{127}$ However, Hersi was stationed in Mogadishu and, as the director of the NTCP and a professor at the University of Mogadishu, he had also other responsibilities on his plate. ${ }^{128}$ FATA's board and the working committee held meetings only once a month ${ }^{129}$ - insufficient to deal with all that could crop up on a daily basis in that time. Brander explained to Sellergren: 'It is difficult to get the Board members together', and 'besides, they cannot really give any absolute rules on how to treat patients'. ${ }^{130}$

FATA's short-course chemotherapy guidelines were similar to the treatment principles that would later become the DOTS strategy. The case-finding was different, but otherwise principles such as fully supervising drug intake and following each case up with a patient register were alike. ${ }^{131}$ However, in 1981-3, the Project was not able to follow these principles through in the field. Perhaps the most pressing reason for FATA launching the Project in Qoryoley had been that it expected the camps to be a more stable, 'realistic' place to administer and monitor the treatment than the rest of Somalia, where nomadism was common. ${ }^{132}$ In practice, however, refugees moved in, out and around the camps. ${ }^{133}$ When people heard how effective the Finnish treatment was, they started coming to the camps from Mogadishu and nearby villages. ${ }^{134}$ By the autumn of 1981, the Project's treatment stations were overcrowded, and the team had to establish additional dispensaries for non-refugees in Qoryoley town and the village of Shalambood. ${ }^{135}$ Sellergren suspected

122 FA, EBA 1981, Hersi to Pätiälä, 21 January 1981.

${ }^{123}$ FA, Sellergren to FATA, 7 February 1981.

${ }^{124}$ Kauttu, op. cit. (note 92), 821.

125 FA, Sellergren to FATA, 29 January 1981.

126 FA, Virmakoski to FATA 18 December 1981

${ }^{127}$ FA, Sellergren to Jorma Pätiälä, 15 March 1981; EBA 1981, Hersi to Brander, 18 May 1981.

128 See, for example, FA, Sellergren to FATA, 3 March 1981.

129 On frequency of meetings: FA, MFB, MWC.

${ }^{130}$ FA, EBA 1981, Brander to Sellergren, 4 May 1981.

131 Plan of Operation, Appendix 2, op. cit. (note 77), 1-2.

132 FA, MFB, 28 May 1980 3/50 $§$ and Appendix 'Yleistilanne Somalian pakolaisleireillä [General Situation in the Refugee Camps] 19.4.-4.5.1980', 2.

133 FA, Sellergren to FATA, 3 March 1981.

${ }^{134}$ FA, Sellergren to FATA, 17 September 1981; Heli Sellergren, op. cit. (note 18), 5; Inari Virmakoski op. cit. (note 18), 3-4.

135 AMFA, 78293 SOM-2, Reports 1982/83, Tor-Leif Sellergren, 'Suomi-Somalia Tuberkuloosiprojekti [Finland-Somalia TB Project] 04.12.1980-31.12.1981', 3; Inari Virmakoski op. cit. (note 18), 4. 
that many patients discontinued their treatment as soon as they started to feel better, ${ }^{136}$ so, in an effort to prevent mobile patients from defaulting, they were sometimes given drugs for a week or so. ${ }^{137}$ Medication was thus not always fully supervised. There were also cases of rifampicin being stolen. ${ }^{138}$

FATA's advice to verify cases bacteriologically was also often disregarded and treatments were sometimes started without a proper sputum sample. Clearly, the Finns felt pressure to start the treatments fast, as not only was the initial contract period short, but case-finding and getting diagnosed patients into treatment lagged during the first months. ${ }^{139}$ After three months in the field, Sellergren explained the situation by stating that 'in the beginning, we might have been focused too one-sidedly on launching the treatments. We wanted to make a good impression and it was also probably the humane thing to do'. ${ }^{140}$ The team probably wanted concrete results before the next negotiations to be able to vindicate their methods. Also, the tuberculosis was more severe than anything they had seen in Finland. ${ }^{141}$ In Somalia, TB was taboo and unsupervised selfmedication was common, so people only came to the clinics when the disease was already further on and more difficult to treat. ${ }^{142}$ In Finland, forty per cent of the patients who entered treatment were bacteriologically negative and had been diagnosed on the basis of X-ray or clinical symptoms. ${ }^{143}$ The Finns, who were used to starting treatment without bacteriological verification, probably regarded it as unnecessary and unethical to wait for such verification when faced with the grim reality in the camps. Sellergren also noted that these hectic conditions explained why both Finnish and Somali team members often failed to collect or annotate the sputum sample properly. ${ }^{144}$ Although the WHO advocated the sputum microscopy as a simple technology, Jones has demonstrated that similar practical problems in collecting and examining samples were also common in Sri Lanka. ${ }^{145}$

In order to stop patients defaulting, Sellergren modified FATA's standard four-drug regimen. According to him, the combination of rifampicin, streptomycin, isoniazid and pyrazinamide was too toxic for the weaker, malnourished refugees, who would suffer from side effects and give up the treatment. ${ }^{146}$ To avoid this, he instigated an initial clinical examination, where the patient's overall condition and previous treatment history were all considered. By September 1981, Sellergren had fifteen different regimens in place. The most common were a three-drug combination of rifampicin, streptomycin and isoniazid (250) used in new cases, and a combination of rifampicin, isoniazid and pyrazinamide (151) for those patients who had been treated for tuberculosis before and might be resistant to isoniazid and/or streptomycin. ${ }^{147}$ During the follow-up phase, the patient was also given the drugs daily rather than intermittently. Sellergren was again worried that intermittence

\footnotetext{
136 FA, Sellergren to FATA, 17 September 1981; 16 October 1981.

${ }^{137}$ FA, EBA 1981, 'Preliminary report of the TB-campagne in Koryole refugee camps and the surrounding area', 2. For more on dispensing drugs to patients, see also FA, Nurse Tuija-Liisa Peltola to FATA, 18 February 1981; Virmakoski to FATA, 18 December 1981.

${ }^{138}$ FA, Virmakoski to FATA, 15 June 1981; laboratory technician Anita Pitkänen to Kajava, 12 August 1981.

${ }^{139}$ FA, EBA 1981, Brander, 'Projektin välimuistio [Project memo]', 24 February 1981.

${ }^{140}$ FA, Sellergren to FATA, 26 April 1981.

${ }^{141}$ FA, Sellergren to FATA, 3 February 1981; X-ray technicians Jorma and Raimo Leisilä to FATA, 26 May 1981.

142 Serkkola, op. cit. (note 34), 46, 97, 128, and, for more on denying and hiding TB, see pages 77-8 especially.

143 Tala, 1978, op. cit. (note 98), 43-7, 47, Härö, op. cit. (note 8), 62.

144 FA, Sellergren to FATA, 1 October 1981.

145 Jones, op. cit. (note 24), 525-6.

${ }^{146}$ FA, Sellergren to FATA, 18 February 1981.

${ }^{147}$ FA, Sellergren to FATA, 17 September 1981 and 'Tables for Sellergren's letter 17 and 19'.
} 
would disrupt treatments as, according to him, the refugees, who were used to daily treatment, did not 'understand anything about it [intermittence]'. ${ }^{148}$ The duration of the treatment also depended on the patient's condition, monitored via X-ray and sputum samples. Usually it would last for nine months, but six- to eight-month treatments were also accepted. ${ }^{149}$ These solutions were based on clinical experience gathered in Finland and practical experience from working in the camps. According to Dr Liisa Parkkali, the three-drug combinations above were all common in Finland. ${ }^{150}$ By prioritising treatment over bacteriological diagnosis, and by optimising it for every patient, Sellergren clearly approached the Project from a clinical perspective where curing every TB case was the priority. His stance was not extraordinary, as similar conflict between clinical perspective and policy formation had taken place in the Madras trials. ${ }^{151}$ Sellergren's approach can be explained by his experience as a clinician in Finland and the treatment-oriented goals of the Project, the success of which were measured by the number of cases detected, treated and cured.

In 1981,11337 people were examined by mass miniature X-ray and 1075 patients were admitted for treatment. ${ }^{152}$ After the first year, the Project seemed quite successful. According to FATA, prevalence of active tuberculosis dropped from 8.5 to 3.1 per cent among those examined within six months. Control X-rays and bacteriological tests also indicated that many difficult streptomycin- and isoniazid-resistant cases had improved with the treatment. ${ }^{153}$ In 1982, the Project was extended to Mogadishu, as the Somalis had planned. ${ }^{154}$ The governmental contract for the years 1982-4, based on a proposal drafted jointly by Hersi and Sellergren, claimed the Project's results proved the effectiveness of the Finnish method of controlling TB in the refugee camps, especially the usefulness of mass scanning with miniature X-ray. ${ }^{155}$ The results were presented at both the IUAT African region meeting in 1981 and the IUAT Conference in Buenos Aires in 1982. ${ }^{156}$

Experiences from the camps, however, also indicated that there were at least some grounds for the earlier criticisms. It had become clear that only a small proportion of patients could be treated with rifampicin - even within the specific Project area - as it was so expensive. In other words, the project had little to no impact on the overall epidemiological situation in Somalia. ${ }^{157}$ This was a problem when it was evaluated from a public health perspective, i.e. whether the Finnish approach benefited the whole population rather than a small number of individual patients. ${ }^{158}$ In March 1982, Dr Ron Waldman,

\footnotetext{
${ }^{148}$ FA, Sellergren to FATA, 26 April 1981.

149 FA, EBA 1982-3, Sellergren, 'Experiences of TB-work in Somalia', 1.

${ }^{150}$ Liisa Parkkali, op. cit. (note 18), 12-13. For more on rifampicin-based three-drug combinations in Finland, see also Tala, op. cit. (note 96), 512; and Karin Matsson, 'Rifampisiini tuberkuloosin hoidossa', Duodecim, 89, 11 (1973), 810.

151 Amrith, op. cit. (note 24), 123-5.

152 FA, EBA 1981, Sellergren, 'The Somalya TB-Project', Appendix: Statistics of the SSTP 1981, 1-2.

${ }^{153}$ FA, EBA 1981, 'Preliminary report of the TB-campagne in Koryole refugee camps and the surrounding area', 4-6; and Sellergren to FATA, 16 August 1981.

${ }^{154}$ For more on Somali agendas for the year 1981, see FA, Sellergren to FATA, 3 March 1981, Appendix 1 'Yusufin ehdotus jatkoprojektiksi [Yusuf Hersi's project proposal] 1981'; and FA, Sellergren to FATA, 17 September 1981.

155 AMFA, 12R SSTP 1982, Plan of Operation 1982-4; For satisfactory results in the refugee camps, see also AMFA, 93-SOM-2. Somalia. 1982/2092, SSTP 1982. File 782; and Somalia: TB-Control Programme, Report of the Evaluation Mission, November 1983, 26.

156 FA, Brander to Sellergren, 7 November 1981; MFB, 9 December 198114 /94 $\S$.

157 FA, Sellergren to FATA, 1 October 1981; 8 November 1981.

158 Amrtih, op. cit. [note 24], 124-5, 128.
} 
one of the refugee health advisors, again bluntly criticised FATA for using methods that Somalia could not afford to continue, let alone expand, once the Finns left. According to him, the Refugee Health Unit (RHU) would never have accepted the Project's treatment strategy. ${ }^{159}$ Dr Eeva Rusanen, who started her work as the team leader in 1982, was told by Brander to not be too 'bothered about' the above comments. ${ }^{160}$ Both FATA and Sellergren replied there was no point using the WHO standard regimen in Somalia as it was ineffective against resistant strains and the patients defaulted because the treatment was too long. ${ }^{161}$ The experience from the camps had nevertheless shown that the Finns would need to modify their methods.

In 1982, the Finnish medical team started to work in Mogadishu, where the number of patients was expected to be even greater. ${ }^{162}$ In early 1982, Hersi suggested that rifampicin be used only for chronic (resistant) cases, so that more patients could be treated. ${ }^{163}$ But, whereas public-health oriented experts considered it to be a problem that only small numbers were being treated, clinically-oriented FATA wanted rifampicin-based regimens as a standard treatment for every patient. It set new restrictions on the admission for treatment instead. From as early as March 1981, active case-finding was disregarded, and the treatment of bacteriologically positive cases prioritised - in line with the standard WHO treatment and the IUAT Project in Tanzania. ${ }^{164}$ In September 1982, Dr Rusanen wrote that the Finnish-Somali team at the UNICEF TB Centre in Mogadishu was limiting X-ray scans to fifty patients per day, and a Somali doctor would then choose two 'suitable, preferably young and fresh cases' for the Project. ${ }^{165}$ The rest were sent to NTCP for the WHO standard treatment. ${ }^{166}$ This method of case-finding thus moved towards more international models, as the importance of sputum microscopy had increased even if $\mathrm{X}$-ray remained the scanning tool for sample collection. According to Liisa Parkkali, who became team leader in 1983, 'clear cases' were still admitted on the basis of X-ray diagnosis. ${ }^{167}$ Such restrictions were sometimes ethically difficult for the medical team to put into practice, ${ }^{168}$ but they made sense from the Project's perspective: it had limited resources, but would be considered successful if the predetermined amount of patients were cured per year.

FATA was more concerned about defaulting patients than the number of treatments, as it directly affected treatment results, was a waste of expensive drugs and might eventually create rifampicin-resistant strains. According to Sellergren's report from 1982, the defaulting rate had been at fifteen per cent in the Qoryoley camps in $1981 .^{169}$ If this figure is accurate, the Project was extremely successful in reducing the rate of defaulting.

\footnotetext{
${ }^{159}$ FA, R. Waldman to A.M. Magan, 29 March 1982; Copy of a letter from the RHU director, Dr Ahmed Magan to UNHCR representative.

${ }^{160}$ FA, EBA 1982-3, Brander to Rusanen, 12 May 1982.

${ }^{161}$ FA, EBA 1982-3, FATA to Finnish Refugee Council, 1982; Sellergren, 'Some Reflexions on Dr Waldman's Comments Concerning the Finnish Tuberculosis Project in Somalia'.

162 FA, Sellergren to FATA, 16 October 1981, 8 November 1981.

163 FA, EBA 1982-3, Sellergren to Brander, 12 February 1982.

164 FA, Sellergren, 'The Somalya TB Project. A Report for the Year 1981'; EBA 1982-3, Brander to the Finnish Team, February 1982.

165 FA, EBA 1982-3, Rusanen to Brander, 29 September 1982.

166 AMFA, 78293 SOM-2. Raportit 1982/83. Eeva Rusanen: 'Suomi-Somalia Tuberkuloosiprojekti [FinlandSomalia TB Project] 1.7.-31.12.1982'.

${ }^{167}$ Liisa Parkkali, op. cit. (note 18), 12-13.

168 FA, EBA, 1982-3, X-ray technician Jorma Leisilä to Brander, 24 April 1982.

${ }^{169}$ FA, EBA 1982-3, Sellergren, Experiences of TB-Work in Somalia, 2.
} 
In comparison, Dr Paul Shears calculated that fifty per cent of the 600 patients given the WHO standard treatment between July 1980 and August 1981 in the Somali Sab'ad refugee camps had defaulted, and of 244 patients still being treated, seventy participated only irregularly. ${ }^{170}$ It is unclear what data the Qoryoley figures are based on though; so far, I have not found clear statistical information on defaulters for the period 1981-3. Another report stated that, by September 1981, 120 of the total of 900 treatments started by that date had ended with defaulting and 170 had been successfully completed. ${ }^{171}$ If we analyse only the treatments that had come to an end $(170$ cured +120 defaulted $=290)$, it seems that forty-four per cent of the patients had defaulted and sixty-six per cent completed the regimen successfully by autumn $1981 .{ }^{172}$ According to Liisa Parkkali, the Finns (herself included) did not realise just how many patients were defaulting until they started using IUAT patient records in 1983-4. ${ }^{173}$

In August 1981, FATA decided to send the nurse Päivi Kokkonen to investigate the defaulting problem in the camps. ${ }^{174}$ Taking a public-health oriented stance, she recommended that, instead of trying to export 'Finnish tuberculosis polyclinics' to Somalia, the Project should improve treatment compliance by intensifying health education and community involvement at all levels, co-operating with primary healthcare services and using more Somali staff. ${ }^{175}$ FATA's solution would remain mainly biomedical: from 1982, the Finns started using an even shorter, six-month course of chemotherapy in Mogadishu, the Qoryoley refugee camps and (from 1983) Kismayo. ${ }^{176}$ The new drug combination was based on international research (justified by Brander with the publication of Wallace Fox $(1981)^{177}$ ). Drug-sensitive patients (new cases) received rifampicin, streptomycin, isoniazid and pyrazinamide daily for two months followed by isoniazid and rifampicin daily for four months. For drug-resistant patients (old cases) streptomycin was replaced with ethambutol. ${ }^{178}$ Concern about rifampicin resistance might have influenced the decision to return to a four-drug combination: streptomycin, rifampicin and isoniazid were a feasible combination in Finland, where resistant TB strains were uncommon, ${ }^{179}$ but in Somalia the same regimen could cause rifampicin resistance in those patients who were already resistant to streptomycin and isoniazid. In 1982, Brander further instructed that patients' sensitivity to drugs should be ascertained before treatment was started and constantly monitored throughout. ${ }^{180}$

In 1981-3, the Finns focused on preventing the defaulting with flexible drug distribution. Despite the shorter treatment time, default rates were calculated to be standing

\footnotetext{
${ }^{170}$ Paul Shears, Tuberculosis Control Programmes in Developing Countries: Oxfam Practical Health Guide No. 4. 2nd edn (Oxford: Oxfam, 1988), 2-4.

${ }^{171}$ FA, EBA 1981, 'Preliminary report of the TB-campaign in Qoryoley refugee camps and surrounding area', 2.

172 It is important to note that 610 of 900 treatments were still ongoing in September 1981 and may have ended with better cure rates. Also, there were no means to identify how many defaulters were actually patients who had died during the treatment. For more on defaulting rates, see annual project reports, 1984-90, stored in FA and AMFA.

${ }^{173}$ Liisa Parkkali, op. cit. (note 18), 19; AMFA, 78293 SOM-2, Raportit 1982/83; Liisa Parkkali, 'Report for the Period of January 1st, 1983 to June 30th, 1983', 3.

174 FA, EBA 1981, Brander to Sellergren and Hersi, 11 September 1981.

175 FA, EBA 1981, Päivi Kokkonen, unnamed report, 3-4; Maija Kajava, op.cit. (note 18), 17, 21.

176 AMFA, Liisa Parkkali, op. cit. (note 173), 1-2.

177 Wallace Fox, 'Whither Short Course Chemotherapy?', Bulletin of the International Union against Tuberculosis, 56, 3-4 (1981), 135-55.

178 FA, EBC 1982-3, Brander to Finnish team, February 1982.

179 On drug resistance in Finland, see Härö, op. cit. (note 8), 66.

${ }^{180}$ FA, EBA 1982-3, Brander to the Somalia-team, February 1982.
} 
at around thirty per cent in 1982 and 1983. Both Rusanen and Parkkali believed the long difficult journey to the clinics were the main cause, so it was common to give patients enough drugs for one to two weeks at a time. ${ }^{181}$ An alternative solution would have been to restrict treatment only to people who lived near the ambulatories and could visit daily, ${ }^{182}$ but this was rejected for both practical and ethical reasons. First, it was impracticable in a country that lacked medical services and, with no IDs, patient registers or even system of addresses, it would have been impossible to verify where the patient lived. Second, the idea of denying care based solely on where the patient lived did not tally with the Finns' humanitarian conception of the Project. ${ }^{183}$ Local realities also caused other challenges. Treatments were disturbed when problems were encountered in regulating, ordering and transporting the drugs. ${ }^{184}$ Finally, the waiting time required for the sensitivity tests was so long that the clinic risked losing contact with patients, so treatments were started before results had come back and only changed later if there was drug resistance. ${ }^{185}$

The Project seems to be among the first to use the short, six-month course in clinical practice within a national tuberculosis control programme in Africa. While the new regimen was launched in Mogadishu in 1982, IUAT started its ground-breaking shortcourse chemotherapy pilot programme in Tanzania. The principles of the DOTS strategy were developed in that pilot programme under the leadership of the IUAT scientific director, Karel Styblo. ${ }^{186}$ The programme was extended district by district to the whole country in 1982-6. Collaborative IUAT projects were also started in Mali, Benin, Kenya, Malawi, Mozambique, Nicaragua, Senegal and Yemen. ${ }^{187}$ Although the FATA papers do not mention them, the Finnish TB specialists were probably aware of these developments. The IUAT leadership was certainly interested, and aware of the treatment carried out in the Somali-Finnish project. Styblo and Annik Rouillon, executive director of the IUAT, offered advice to FATA in late 1982, and FATA members enthusiastically took part in IUAT conferences and meetings. ${ }^{188}$ Procuring cheaper drugs through IUAT networks allowed FATA to increase the number of patients in the Project from 1000 in 1982 to 3000 in 1983. ${ }^{189}$

Although FATA was willing to collaborate with IUAT on its own terms, it wanted to stay in charge of the Project. This became evident when the DIDC asked Karel Styblo to evaluate the Project at the end of 1983. The small number of patients, the cost and the rifampicin resistance became pressing issues again. Both the Somalia-Finland Project and IUAT's Tanzania programme were carried out as a specialised, vertical programmes based on high medical standards. However, their main difference was that the Tanzania programme had a country-wide approach on TB control. Thus, IUAT - like the WHO - prioritised the treatment of the masses. The Tanzania programme used the cheapest possible short-course treatment that lasted eight months and contained rifampicin

181 AMFA, 78293 SOM-2, Raportit 1982/83; Eeva Rusanen, 'Suomi-Somalia Tuberkuloosiprojekti 1.7.-31.12.1982'; Liisa Parkkali, op. cit. (note 173).

182 FA, Brander to Sellergren and the team, 7 November 1981.

183 FA, Sellergren to FATA, 14 December 1981. See also Heli Sellergren, op. cit. (note 18), 5.

${ }^{184}$ FA, EBA 1982-3, Liisa Parkali to Brander, 2 March 1983; Maija Kajava op. cit. (note 18), 5.

185 Liisa Parkkali, op. cit. (note 18), 12-13.

186 McMillen, op. cit. (note 1), 190-1.

${ }^{187}$ Rouillon, op. cit. (note 26), 163-5.

${ }^{188}$ FA, Brander to Sellergren and team, 7 November 1981. See also Maija Kajava, op. cit. (note 18), 2.

${ }^{189}$ FA, EBA 1982-3, Brander, 'Somaliahanke Raportti [Somalia Project Report]' 28 December 1982. 
only in the two-month long initial phase. ${ }^{190}$ The Somalia-Finland Project focused on curing a specific number of patients in the project area, and used the shorter and more expensive six-month regimen that contained rifampicin in both the initial and the followup phases. ${ }^{191}$ Another significant difference was that the Tanzania programme prioritised the strict supervision of drug intake. Therefore, patients were hospitalised during the initial phase of IUAT treatment to ensure that taking the rifampicin was fully supervised. The hospitalisation was against the WHO guidelines that recommended ambulatory treatment for the developing world. ${ }^{192}$ In the evaluation report, Styblo pointed out that the supervision had not been possible with FATA's ambulatory treatment. He recommended that the Finns try out the cheaper IUAT regimen in routine conditions as a 'pilot study', but otherwise prioritise supporting the NTCP in improving their use of the WHO standard treatment, so that more patients could be treated. He reasoned that it would take several years to know whether short-course chemotherapy is feasible in Somalia'. ${ }^{193}$ It is good to note that even the Tanzania programme could not carry out all its principles in clinical practice. ${ }^{194}$ Thus, the Somalia-Finland Project was not extraordinary in its incapability to fully follow high medical standards.

Styblo's recommendations might seem odd in the light of his work in Tanzania, which challenged the WHO standard treatment. However, his stance might be more understandable in the light of his concern about the rifampicin resistance and costs. It is important to note that the short-course chemotherapy had been tested in Tanzania only approximately a little over a year when Styblo evaluated the Somali-Finland Project. ${ }^{195}$ Gradmann has stated that the Tanzania programme became particularly valuable because it had used both the WHO standard treatment and the short-course chemotherapy, and could therefore convincingly argue for the latter. ${ }^{196}$ Styblo clearly wanted this testing to happen in Somalia also before changing the regimen. He pointed out that there were no reliable, systematically gathered data on the results of the WHO regimen. He worried about the development of rifampicin resistance and was not fully convinced that Finnish-Somali teams could provide strictly supervised treatment in Somalia. He also evaluated the Project from the viewpoint of building a nationwide TB strategy. Since the Finns could afford to treat only a small proportion of patients with short-course chemotherapy, it made sense from the public health perspective to put more emphasis on the majority of the cases under standard treatment. ${ }^{197}$

FATA did not accept Styblo's recommendation to focus on the WHO standard treatment. However, the Project started to hospitalise those patients who were at risk of default (i.e. lived far away from the TB services), supervised rifampicin intake more strictly and included eight-month treatment to the programme. These adjustments towards the IUAT model were highly influenced by the fact that they were promoted by DIDC, which took a more active role in supervision after the evaluation. Hospitalisation and supervision also made sense for the Finnish TB specialists, who saw defaulting as a problem. However,

\footnotetext{
190 Gradmann, op. cit. (note 15), 328-9, 333. Rouillon, op. cit. (note 26), 163-5.

191 Report of the Evaluation Mission 1983, op. cit. (note 155), 41-42.

192 Gradmann, op. cit. (note 15), 326, 330.

193 Report of the Evaluation Mission 1983, op. cit. (note 155), 35-43. See also Liisa Parkkali. op. cit. (note 18), $18-20,23$.

194 Gradmann 2019, op. cit. (note 15), 332-6.

195 Ibid., 329.

196 Ibid., 341.

197 Report of the Evaluation Mission 1983, op. cit. (note 155), 35-42.
} 
hospitalisation only became possible after 1983, when the DIDC decided to fund the construction and renovation of TB centres. The six-month course was still preferred by FATA and frequently used in daily supervision. Although most of the patients were sputum positive, sputum negative cases were also treated. ${ }^{198}$

It is important to notice that, after early 1982, there are no sources indicating that Hersi (or $\mathrm{MOH}$ ) opposed the use of short-course chemotherapy. In the summer of 1982, Hersi actually defended the use of rifampicin-based regimens in the refugee camps, in a letter to the Finnish refugee council. In 1983, Dr Parkkali stated that there were no disagreements between herself and Hersi over medical issues. ${ }^{199}$ Since the Somalis involved in the Project did not shy away from expressing their differing views on other occasions, it is likely that they would have voiced their objections if they had disagreed about the treatments after the evaluation. It seems that the Somali leadership had developed a more positive understanding of the rifampicin-based regimens over time. On the other hand, the support may also have been first partly tactical, as a way of securing further funding for TB control. As the disease was not a priority in global health during the 1980s, it might have been difficult to find another donor.

\section{Conclusion}

The discussion on feasible treatment in the Somalia-Finland Tuberculosis Control Project demonstrates that the methods thriving in closely supervised trials and in industrialised countries were difficult to transfer successfully to the clinical practice in the developing world. The Project took place at a time when the short-course regimens were just beginning to be clinically tested. Finns participated in this work by exporting the Finnish model of TB control to Somalia. However, it soon became evident that this approach was not feasible as such in the local context. The Project could not fully follow high medical standards planned in Finland with limited practical knowledge of the local conditions. It had to adapt towards global models, especially towards the IUAT Tanzania programme, that were better suited for managing the oversupply of patients. However, despite criticism from the medical experts advocating the WHO or the IUAT model, Finnish preferences on effective but expensive practices such as X-ray scanning, treating bacteriologically negative patients and using the six-month regimen also remained an integral part of the Project.

The article shows that donor perspective on resources, objectives and local realities determined what was seen as feasible treatment. First, it argues that FATA's decision to deviate from the WHO and IUAT models should be seen in the context of the broader international debate between clinical scientists and public health-oriented tuberculosis experts and organisations. The former, especially experts working directly in the field, put emphasis on cutting the chain of infection fast by curing individual patients. From this perspective, using regimens that were difficult for the patients to follow and caused resistance only made the TB problem worse. FATA's decision had strong clinical grounds. Finns could afford to treat significantly fewer people with short-course therapy, but could also be relatively sure that the patients who stayed in treatment were cured. X-ray scanning and the shorter treatment regimen were also rational choices in the light of FATA's past experiences in Finland and its interest in international TB work. FATA was a scientificallyoriented organisation dominated by clinicians. By implementing 'new' strategies, the

198 For later treatments, see for example FA. Semi-annual report 1.1.-30.6.1988, 28-37.

${ }^{199}$ FA, EBA 1982-3, Liisa Parkkali to Brander, 19 February 1983. 
Association could participate in the development of TB control models for developing countries and seek international recognition for 'Finnish expertise'. Meanwhile, the public health approach, endorsed by the WHO, reviewed treatment on a mass level and aimed for nationwide coverage of healthcare services. Hersi's approach was public health-oriented: as director of the NTCP, his main concern was to expand the treatment nationwide. X-ray screenings and an extensive use of expensive rifampicin did not seem like the best way to achieve this when only a fraction of the infected population could be treated.

Second, the article shows that the Finnish clinical approach was possible because the work was conducted as a bilateral development aid. Although the WHO TB strategy and PHC policy were understood as the official guidelines for the developing world, the Project could ignore them due to the extensive governmental funding, project approach and firm belief in Finnish medical knowledge. This gave the Project a strong identity as a vertical initiative operating under special agreement outside national policy lines. The project logic explains why FATA did not consider the high costs to be a major problem. Unlike the IUAT Tanzania programme, the Somalia-Finland Project was in practice a geographically and temporary limited intervention that focused on immediate, treatmentoriented objectives. The Finns nevertheless understood very well that their work covered only a small percentage of the cases and had, at best, only a minimal effect on the prevalence of TB in Somalia; but it was irrelevant to FATA at this point whether their methods could be extended fast to the whole country. The initiative was successful if the medical team could treat and cure a specific number of the patients within each contract period. From this viewpoint, the Finns were not responsible for the developments that took place outside the geographical or temporal scope of their project. The use of less effective methods made no sense to FATA or the medical staff involved with patients on a daily basis. 